\title{
THE ECONOMICAL AND FINACIAL IMPLICATIONS OF RENEWABLE ENERGY SOURCES
}

\author{
Alexandra Maria BELE (LĂCĂTUȘ) \\ ${ }^{1}$ Doctoral School of Economic Sciences, University of Oradea, Oradea, Romania \\ lacatusalex@yahoo.com
}

\begin{abstract}
More and more often, we talk about the use of renewable energy from the perspective of environmental protection. Competitive pressure in which reliability and efficiency are the key elements in capital development that shape the development plan of countries every year. However, we cannot look at this issue only from a climatic point of view. On a large scale, the production and the development of industries must thrive to the new standards, adapting also from the technological and financial point of view. The most visible effects are quantifiable in the form of employment, increase or decrease in GDP, dynamics of budget revenues and expenditures, applied taxonomy, and investment impact. In no country does the improvement of renewable energy take place without financial, social, and political support. EU countries have decided to allocate significant public funds under various support schemes for the progress of this sector. Accelerating the development of renewable energy sources (RES) also involves the introduction of mechanisms involving the use of private capital. In turn, this has effects on the level of local acceptance for development projects. In other words, this article presents first of all a synthesis of the key elements of the literature, dealing with the scientific, technical, economic, financial and environmental elements. The most important aspect is related to the contribution of the six renewable energy sources to the achievement of sustainable objectives. The purpose of this article is to provide information on how European Union countries have managed both fiscal and economic revenues from renewable energy sources. In order to establish the economic and financial efficiency of renewable energy sources, the mechanism and functionality of pricing systems were studied. The progress made by the countries studied is determined in particular by the degree of achievement of the objectives imposed by the European Union. Presenting the latest trends in RES, we pointed out the systems that support the development of renewable energy through solutions adopted as financial and environmental measures.
\end{abstract}

Keywords: Renewable Energy, Finance, Renewable energy financing, Innovative energy finance.

JEL Classification: Q4, Q5, H23

\section{Introduction}

The demand for renewable energy has grown in recent years. Contemporary society has understood that the use of these resources ensures sustainable economic and social development and at the same time helps the well-being of the green environment. First of all, every society needs energy to meet its basic 
needs and to make production processes work normally. In other words, renewable energy sources play a key role in both the delivery of energy services and climate change mitigation. Starting from the premise that renewable resources have a huge potential for economic development, this paper captures the current contribution of these resources from a financial point of view. Thus, they revolve around revenues and costs, tariff barriers and financing instruments.

As we well know, energy is the basis of the development of modern civilization. For this reason, it is difficult to estimate the quality of life in a society with a developed energy. The energy sector is gradually eliminating the raw forms of work, contributing to the increase of the greatest value for humanity - the increase of individual freedom. The only way to deal with probably the most important problems today - environmental degradation, climate change and all the harmful consequences for humans and the planet as a whole is to use renewable sources. The issue of the possibility of resolving the environmental situation and reducing global climate change processes has been repeatedly raised by the world community. Aware of the seriousness of the problem and the consequences it can have at the international level, countries are trying to make every effort to solve it.

Although there is no widely accepted definition for what we call energy efficiency, some authors such as Bhattacharyya (2011) believe that most approaches are based on the simple relationship between the, the output of a useful process or energy input into a process" (Filippini, Massimo, Hunt, Lester C., 2015). Looking at efficiency, energy does not produce outputs. This is accompanied by the contribution of certain elements such as capital to produce certain achievements (Bian, Hu, Wang, \& Xu, 2016).

\section{Literature review}

The Paris Agreement was an extremely important document for sustainable development. At the summit, 192 countries adopted a new global climate agreement, which replaced the Kyoto Protocol and aimed to stop global warming. $\mathrm{He}$ was the promoter of the meeting of the representatives of the UN member states in 2015, which resulted in a project entitled "Transforming our World: The 2030 Agenda for Sustainable Development". It identifies 17 global goals for sustainable development, and their purpose is to provide an opportunity to address at least in part the most pressing issues facing humanity today. These include combating poverty, hunger, improving health, quality education, gender equality, clean water and sanitation, renewable energy, decent work and growth, innovation, and infrastructure, reducing inequality, sustainable development of cities and communities, responsible consumption, control climate, underwater and land life, peace and justice, partnership for goals. And as can be deduced, the priority is the development of renewable energy, because it is a precondition for solving all other problems (United Nations, 2015).

Renewable energy is an inexhaustible source of energy from an ecological point of view, which does not change the functional structure of the Earth and which offers an opportunity to reduce the burden of the resource base and the global consumption of resources. In other words, it leads to overcoming poverty and responsible consumption (Ukrainian Association of Renewable Energy, 2021). 
Since the publication of the Brundtland report in 1987, concerns about sustainable development have led us to prefer the term renewable energy to the terms "alternative energy" or "new and renewable energy". Focused on the regeneration criterion, the current terminology covers several types of energy sources that do not exactly match the previous terms, more focused on the diversification of sources (energy security perspective) or technological innovation. It is common to define renewable energies as opposed to fossil fuels such as oil, coal or gas and whose natural formation takes several thousand years. However, the establishment of renewable energy lists is common in both the United States and Europe, but their nature is both imperative and exhaustive (Febvre, 2010).

Beyond these terminological meanings, the most common definition of renewable energy is given by Directive 2009/28 / EC, respectively by Art.2 which says that "energy from renewable sources" means "energy from non-fossil renewable energy". In this category we have,, hydroelectric power, aerothermal, biomass, geothermal, hydrothermal and ocean energy, wind, solar, biomass, waste fermentation gas, wastewater treatment plants and biogas " (European Parliament, 2009).

\section{Economic and financial efficiency of renewable energy sources}

An important aspect to be clarified is related to the efficiency of these energy resources. First of all, we will see this as a strategy that reduces energy consumption, for the same service provided and leads to a reduction in ecological, economic and social costs related to energy production and consumption while allowing an increase in the quality of life of all. the inhabitants of the planet and future generations (Cochet, 2000). In other words, efficiency itself is given in the capacity to deal with global economic crises and to avoid them by managing the multiple environmental constraints.

Currently, the GDP of each country is especially important because it shows the size of the market and the purchasing power of residents. Apergis and Payne (2010), using variables such as capital formation, GDP, labour, and renewable energy consumption, demonstrated that there is a two-way relationship between economic growth and renewable energy consumption.

Classical and neoclassical economists did not explicitly consider the energy factor in their production function. In the days of the classics, the economy was linked to land, labour and capital. That is why we do not have the energy applied in the production function. But over the years, the importance of energy has increased through industrialization. D.I. Stern, C.J. Cleveland (2004) divides neoclassical economics growth patterns into three ideologies.

The first theory insists that technological variations are the most important factors influencing economic growth and production function. In this case, first, the economy reaches a level of equilibrium, when improving technology develops economic growth rather than capital (BEHNAME, 2012).

Energy efficiency transforms the common vision of energy as a factor in power and profit into a vision of energy in response to needs. The RES classification crosses quite different levels both in terms of market organization and public intervention in favour of their development. Obviously, the renewable energy market is by far the most advanced, following in this respect the electricity market in general, the peculiarity of the latter is that it can be transported and changed in 
real time. Thus, various investment support mechanisms have emerged, such as tax exemptions or tax reductions, investment aid, direct price support or tax refunds (Cochet, 2000).

In studied literature, the classification of energy instrument mechanisms, by their dichotomous nature are accentuated by supply or demand stimulation systems. They aim to stimulate the increase of installed capacity or energy production. In practice, however, two basic mechanisms can be distinguished that have become the basis for the operation of various support systems to produce energy from renewable sources in EU countries: the price system and the system for forming the quantities of energy generated, also called quota (UNEP, 2012).

The implementation of the provisions of Directive 2001/77 / EC of the European Parliament and of the Council on the promotion of electricity from renewable sources in the internal market in electricity brings benefits in the form of increasing the share of renewable energy sources in the country's energy balance. comprehensive investment in renewable energy (European Parliament and the Council, 2001). To implement energy efficient solution, it is necessary to have a economic rationale approach. First this solution must be highly cost-effective, before are made any investments in order to have options with expensive low carbon (R. Cowart, 2014).

Due to the fact that energy is used in several different processes it is necessary to use a diversity of instruments. One problem in this is the mixing of these energy efficiency tools that can lead to targeting difficulties (Rosenow, Kern, \& Rogge, 2017).

From a terminological point of view, it is necessary to make the distinguish between energy efficiency and energy saving. These concepts must be viewed separately, as their outcome does not always coincide. Decrease in energy efficiency does not always lead to energy savings. In other words, the two terms exist and operate independently. This is due to the 'rebound effect' which involves offsetting efficiency improvements by improving comfort or use in larger quantities (Malinauskaite, and Others, 2019)

Based on this principle, there are several mechanisms to support renewable energy sources. According to the regulatory method, we find the tariff system, used in most countries. It is set in advance for a longer period, while the price indicates if the tariff is paid to renewable energy producers by the energy distributors, who then transfer these costs to the transmission system operator (s). The final cost of the support mechanism is born by the final energy consumers (Couture \& Gagnon, 2010).

One support mechanism for energy producers from renewable energy sources is the use of green certificates. They are a significant support for companies operating in this industry. RES plants are in many cases technologically complex (biogas plants) and involve high investment costs. To help companies that produce energy from renewable sources, the European Union offers them assistance in the form of a certificate of origin (known as green certificates), which is sold on the open market (EUROPEAN COMMISSION, 2011).

In other words, green certificates, granted monthly to producers by TSOs, can be sold to suppliers on the centralized market of green certificates and / or on the market of bilateral contracts. Manufacturers sell their electricity on the electricity market at the market price (for conventional electricity). Selling green certificates 
to suppliers brings them additional revenue to cover the higher costs of using renewable energy sources. The electricity market and the green certificates market are separate and operate independently (EUROPEAN COMMISSION, 2011).

\section{The research methodology and results}

First of all, the study starts by analysing renewable energy investments at a global, and European level. However, special attention was paid to Romania's position in this context compared to other EU Member States. Thus, in the case of financial instruments, balance sheet financing, grants, project-level debt, and project-level equity were taken into account. In particular, the analysis includes the analysis of investments in the field of electricity which are based on the following technologies Hydropower, Wind Energy, Geothermal Energy, Solar Energy, Biofuels, Biomass and Biogas.

This article is based on empirical data extracted from a wide range of primary and secondary sources. These have been delimited according to the private or public nature of the financial and investment flows. Regarding the financing of renewable sources, it includes data related to the revenues and costs of the components that directly contribute to the operation of the system. Moreover, to emphasize the special role that these resources play in the economic and financial dynamics of European countries, but especially we analysed the evolution of green certificates as some of the most innovative and profitable green financing instruments.

\subsection{Energy efficiency and financial implications}

Currently, all EU Member States have implemented support tools for the development of renewable energy. The financial instruments used indicate that it is possible to combine different types of financing from different fields of application depending on the level of advancement of technological and economic development of the market. The result is the efficiency and effectiveness of the use of these sources. Thus, in the following analysis we followed the evolution of the indicator indicating energy efficiency based on data provided by (Eurostat, 2021) from 1990 to 2019. The indicator measures the level of energy consumption and the distance from the 2020/2030 objectives. Saving energy could improve security of energy supply by reducing dependence on fuel imports. From this it can be deduced that the improvement of energy efficiency leads to the prosperity of the competences of European industry and services, and for households it is reflected in the reduction of energy costs. According to data from (Eurostat, 2021) energy savings could also help reduce GHG emissions from fuel combustion. Quantities of energy are expressed in fuel-specific units such as in thousands of tonnes, in Gigawatt-hours or terajoules (TJ). The energy efficiency indicators included in this data set are 1000000 tonnes of oil equivalent (Mtoe).

In the chart below, the first five countries with the highest degree of energy efficiency have been selected. This category includes Germany, Spain, France, Italy and Poland. We also took by comparison the situation of Romania to determine its progress in relation to the EU level towards Europe 2020 target for 
energy efficiency and the stage of development of the objectives defined in Directive 2012/27 / EU on energy efficiency. First, a constant trend can be noticed throughout the analysed duration, without major fluctuations. Between 1990-2006, a gradual increase can be observed, after which a slight decrease begins until 2014 when the trend becomes a constant one. The most energy efficient country is Germany with a maximum of 332.75 Mtoe reached in 2006 and a minimum of 282.71 Mtoe in 2019. In 2nd place is France with a maximum of 260.92 Mtoe in 2005, followed by Italy with 180.83 Mtoe, Spain with 138.85 Mtoe and Poland with 101 Mtoe in 2018.

According to Directive 2012/27 / EU the target values for primary energy 2020 for the European Union must be less than 1483 Mtoe or for final energy around 1086 Mtoe. In addition, for 2030, primary energy Mtoe of energy consumption must not exceed 1273 Mtoe and for final energy less than 956 Mtoe. Regarding Romania, the values reported at the level of the European Union are much below average. Since 1990, the trend has been downward from 62.36 Mtoe in 1990 to 31.97 in 2019. Compared to other countries, if we follow the trend in 2019 , we can say that Romania's energy efficiency is $0,32 \%$ compared to the value reached by Poland and $0.26 \%$ compared to Spain.

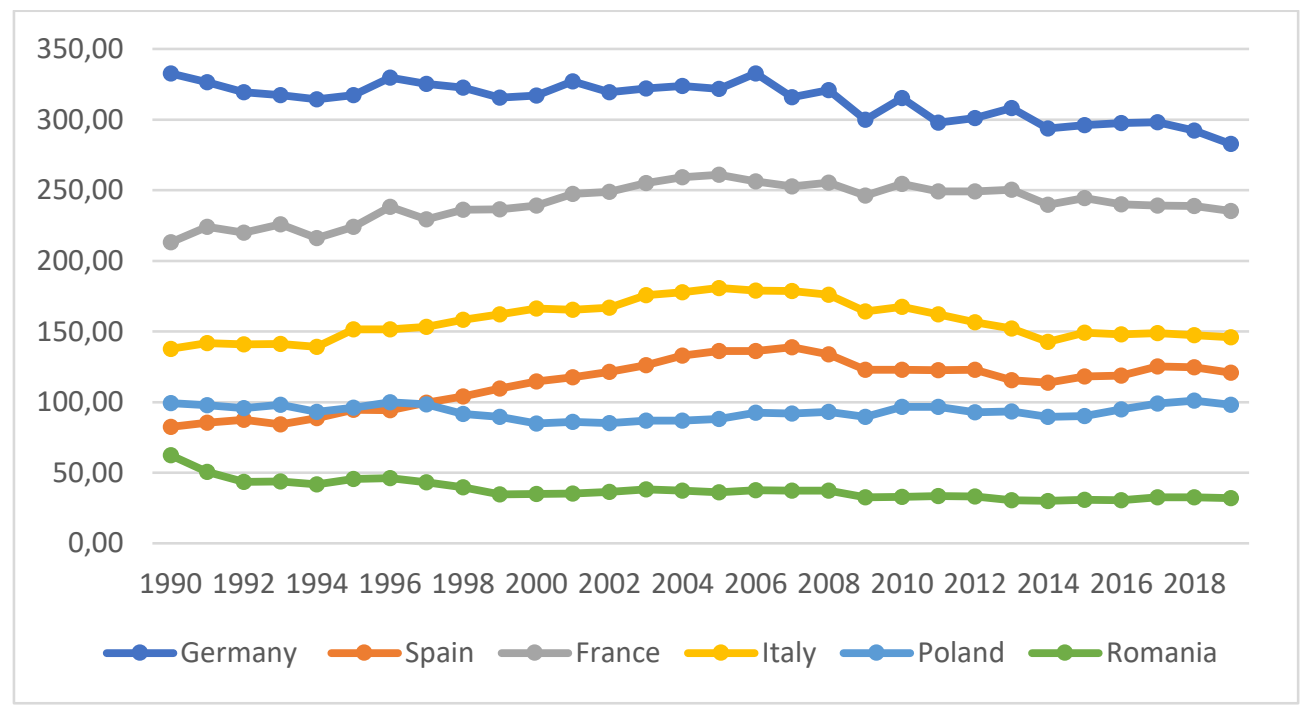

Figure 1: The most energy efficient countries in EU

Source: own editing based on data from EUROSTAT

From a fiscal point of view, energy efficiency is reflected in the revenues collected from energy taxes and duties. In this sense, we followed the evolution of energy taxes considered an indicator of the efficiency of renewable resources. Moreover, with the help of data collected from EUROSTAT, the progress made by the countries of the European Union was monitored in order to achieve the objective of efficiency in terms of resource use but also for the correct setting of prices. Environmental taxation has had a major influence on the dynamics of energy taxes, especially since the tax base is a physical unit with a negative impact on the 
environment. The studied period is between 1995-2019 and includes EU member states. According to EUROSTAT (2021) the indicator measures the total amount of energy tax revenues in millions of euros. It indicates the dimensions that energy taxes take in monetary units to supplement the quotas of energy taxes paid by the consumer. Energy taxes are a subcategory of environmental taxes in addition to taxes on pollution, resources, and transport.

First of all, the attention was focused on the situation of Romania compared to the other EU states. Thus, to be able to show how many times the level decreased or increased compared to the base period, we calculated the fixed base indicators according to the following calculation relation:

$$
I_{t / 1}=\frac{y_{t}}{y_{1}}
$$

At the same time, to show how many times, the level of the indicator increased or decreased compared to the previous period, indices based on the chain were calculated according to the following calculation formula:

$$
I_{t} /_{t-1}=\frac{y_{t}}{y_{t}-1}
$$

From these two equations we can conclude that: $I_{t} / 1=\Pi I_{t} / t-1$.

This shows us that the ratio of the level of the indicator to be compared and the level of the indicator used as a basis for comparison expresses the extent to which the phenomenon y changed during the period considered.

In the chart below we have transposed the situation of the indices with chain base starting from 1996 and until 2019 for Romania in terms of energy taxes. Overall, the trend is constant, with major fluctuations until 2003. The highest increase between 1996/1997 was 1.80202 and 1.298461 between 1997/1998. It is noteworthy that starting with $2017 / 2016$ began a steady progress that reached 1.177895. The situation of fixed-base indices for energy taxes in Romania was reported to 2008 as the base year due to the fact that in that period new laws were introduced that favoured the green tax system. As we can notice, the trend is an ascending one with small fluctuations between the years 2000-2003, respectively 2007-2011. The highest increase compared to the previous year was recorded in 2019 being 2.239002 , respectively 1.900851 in 2018 . 


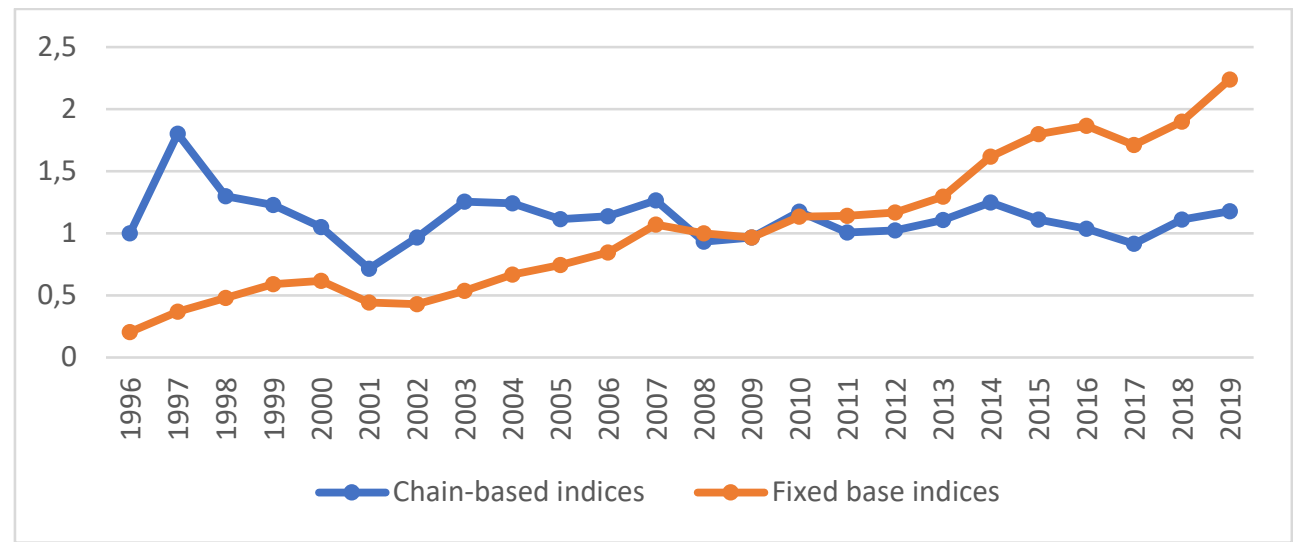

Figure 2: The index with the chain base of energy taxes in Romania Source: own editing based on data from EUROSTAT

The first category analysed is that of the states with the highest revenues from energy taxes. This includes Germany, Italy, France, Spain, the Netherlands, Sweden, Austria, Poland, and Belgium. The trend is a constant one that follows an ascending slope, without major fluctuations. However, some major fluctuations can be noticed, especially in Germany, where the peak reached in 2003 in the amount of EUR 50,473 million suffered a decrease of up to EUR 45,627 million in 2007. The increase in energy tax revenues in the period 2002-2007 is due to in the principle of introducing a national strategy and climate protection programs that have led to special tax treatments (Rosenberg, Schopp, Neuhoff, \& Vasa, 2011). With a considerable difference, we note the evolution of France, but especially of Italy, which although it had a constant trend until 2008, starting with 2009 had a significant increase of up to 47,453 million euros. Compared to this level of taxes, Romania is well below the average of the first countries, more precisely in 2019 the accumulated energy taxes represent $0.09 \%$ of the value of revenues from energy taxes in Germany. 


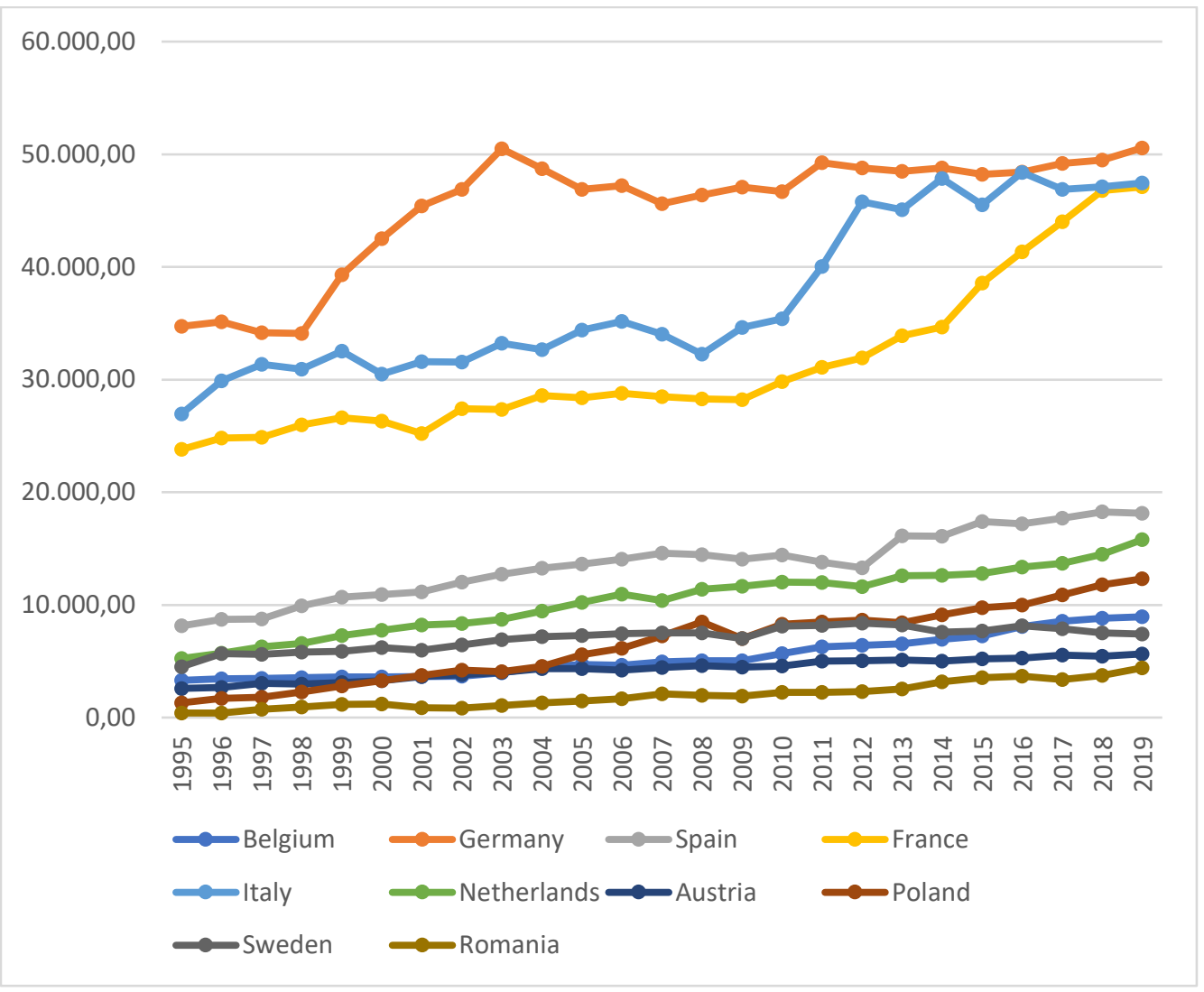

\section{Figure 3: The highest revenues from energy taxes in the European Union}

Source: own editing based on data from EUROSTAT

\subsection{Financial investment trends of Renewable Energy}

One of the European Union's priorities is to develop the energy sector using efficient technologies. Reducing the costs of green energy procurement and achieving leadership in the use of low-carbon technologies have been key objectives for economic development. This cannot be achieved without specific funding mechanisms. Thus, the analysis of the study begins with an overview of global investment trends in renewable energy. Thus, the first graph is based on data collected from (IRENA, 2020) from 2013 to 2018. 


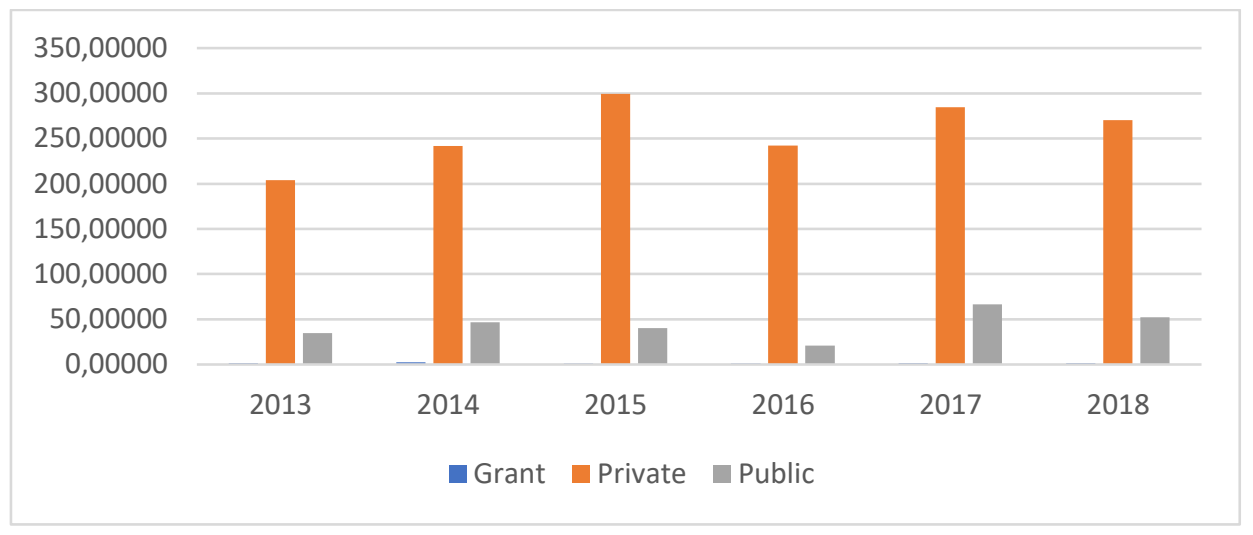

Figure 4: Global investment trends in renewable energy Source: own editing based on data from IRENA

A first important aspect to mention is related to the fact that financial sources are given by three categories: grants, private and public sources. As we can see from the chart below, private financing has the largest share. On average, private funding greatly covers the contribution of the other two categories. The smallest investments were based on grants, and the lowest values were recorded in 2015 amounting to USD 0.94488 trillion, with a remarkable decrease from a maximum of USD 2.32416 trillion. In terms of public sources, they fluctuated significantly, especially between 2015-2017, when there was a halving of USD 4050281 billion, following a rapid increase of up to USD 6664978 billion.

In terms of the potential for financing energy investments, the most important source is funds from the European Investment Bank (EIB), whose lending activity is in line with the EU's strategic development directions. EIB funds are offered in the form of loans and lines of credit. The first form is addressed to public institutions, banks and large private companies. The credit line mechanism is intended for financial institutions that separate funds allocated in accordance with the EIB's investment priorities.

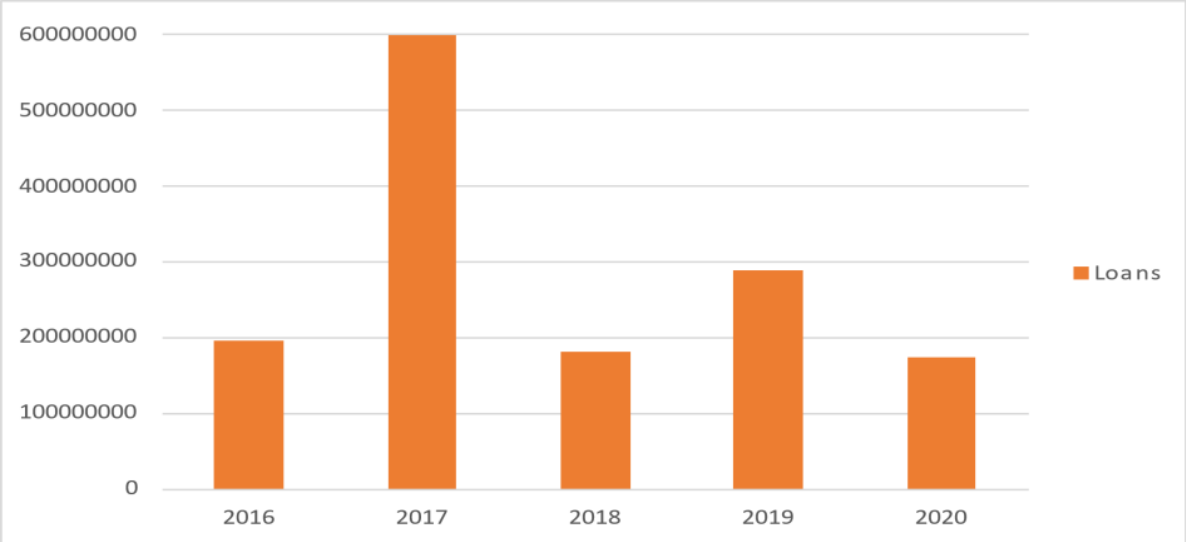

Figure 5: Loans allocated for energy purposes

Source: own editing based on data from European Investment Bank 
The graphic shows the evolution of EIB lending from 2016 to 2020. In the period under review, the amount of EIB funds allocated for energy purposes amounted to over EUR 1,438,383,681. Although there are significant fluctuations, especially between the years 2017-2018 when there is a sharp decrease from EUR $600,060,670$ to EUR $180,200,000$. In 2017, the largest loans were granted in the amount of EUR 100,820,806 for "Infrastructure fund investing in large energy projects with a focus on renewable energy". Another significant amount of EUR $55,000,000$ was awarded for the Pan-European infrastructure fund targeting transport energy renewable energy efficiency ICT (broadband) and water treatment sectors. At the opposite pole, the lowest investments of 1,750,432 EUR were granted for "Equity-type loan to Fund focusing on energy transport wastewater telecommunications and social infrastructure investments" mainly in Nordic countries. At the same time, the smallest loans were granted in 2020. A significant amount of EUR $61,000,000$ was granted for the fund providing debt to developers of small and medium sized RE projects and Energy Transition projects across the EU with a $50 \%$ focus on France. At the same time, EUR 40,000,000 has been allocated for investment in an equity fund providing growth capital to SMEs in the energy transition sector through minority equity participations, while EUR $30,000,000$ is top-up fund to be established alongside Eiffel Energy Transition Fund with the aim of providing funding to renewable energy project developers that face scarcity of funding in the delivery of projects due to disruption caused in lending markets and project cycles as a result of COVID-19.

\section{Conclusions}

In conclusion, the energy sector has an important contribution to the sustainable growth of the economy. The global and European priority is the development of renewable energy. Energy efficiency requires the intelligent use of financing mechanisms and the instruments that govern them. Accelerating the need for development requires creating a balance between public and private investment. Energy tax regulations act as a lever in optimizing taxes and duties in order to stabilize socio-economic processes. Based on the analysis, it can be argued that the budget schemes have encouraged the increase of fiscal revenues. In this sense, we can note that there were no major fluctuations, the trend being kept constant. However, the differences in energy taxes between EU countries are considerable. In other words, it is advisable to use low tax rates with a limited number of tax benefits, as this stimulates the real sector of the economy. Germany, Spain, France are the countries that are most energy efficient, both in terms of investments made in this sector and in terms of the financial leverage used. As for Romania, since 2007 there can be a development in this sector, but from a financial point of view it can be said that it is below the EU average.

As can be seen, European funds largely support the development of renewable energy sources and market mechanisms. The demand for energy produced depends directly on the pricing system, but also on the control of production volume. RES installations are in many cases technologically complex and require high investment costs. In this regard, countries have opted for assistance in the 
form of grants or loans. At the same time, an innovative and increasingly used financing tool is the green certificate, and its development prospects are becoming increasingly attractive to investors.

\section{References}

1. Apergis N., Payne J.E. 2010a, Renewable energy consumption and economic growth: evidence from a panel of OECD countries. Energy Policy; 38:656-60;

https://econpapers.repec.org/article/eeeenepol/v_3a38_3ay_3a2010_3ai_3a1_3ap 3a656-660.htm.

2. $\quad$ Apergis N., Payne J.E. 2010b, Renewable energy consumption and growth in Eurasia. Energy Econ, forthcoming; https://ideas.repec.org/a/eee/eneeco/v32y2010i6p1392-1397.html

3. BEHNAME, M. (2012). LA CONSOMMATION D'ENERGIE RENOUVELABLE ET LA CROISSANCE ECONOMIQUE DANS L'EUROPE DE L'OUEST. Available https://revecon.ro/articles/2012-2/2012-2-10.pdf

4. Cochet, Y. (2000). Stratégie et moyens de développement de l'efficacité énergétique et des sources d'énergie renouvelables en France. Available https://www.vie-publique.fr/sites/default/files/rapport/pdf/014000086.pdf 5. COMISIA EUROPEANĂ. (2011). Certificate verzi pentru promovarea producerii energiei electrice. Available https://ec.europa.eu/competition/state_aid/cases/240906/240906_1249037_223_2. pdf

6. Couture, T., \& Gagnon, Y. (2010). An analysis of feed-in tariff remuneration models: Implications for renewable energy investment. Energy Policy, 955-965. Available https://www.sciencedirect.com/science/article/abs/pii/S0301421509007940 7. European Parliament and of the Council. (2001). Directive 2001/77/EC of the European Parliament and of the Council. Available https://eurlex.europa.eu/eli/dir/2001/77/oj

8. EUROPEAN PARLIAMENT. (2009). DIRECTIVE 2009/28/EC OF THE EUROPEAN PARLIAMENT AND OF THE COUNCIL of 23 April 2009 on the promotion of the use of energy from renewable sources and amending and subsequently repealing Directives 2001/77/EC and 2003/30/EC. Official Journal of the European Union. Available https://eur-lex.europa.eu/legalcontent/EN/TXT/PDF/?uri=CELEX:32009L0028\&from=RO 9. EUROSTAT. (2021, March). Energy taxes. Available https://ec.europa.eu/eurostat/cache/metadata/EN/t2020_rt300_esmsip2.htm 10. Febvre, C. (2010). Energies renouvelables: comparaison entre le droit des Etats-Unis et de l'Union européenne. Available https://www.lepetitjuriste.fr/wpcontent/uploads/2011/05/PT\%20Energies\%20renouvelables\%20comparaison\%20 entre\%20le\%20droit\%20des\%20Etats\%20Unis\%20et\%20de\%201\%20Union\%20eu rop\%C3\%A9enne.pdf

11. HE EUROPEAN PARLIAMENT AND THE COUNCIL OF THE EUROPEAN UNION. (2012, October 25). DIRECTIVE 2012/27/EU OF THE EUROPEAN PARLIAMENT AND OF THE COUNCIL. Available https://eur-lex.europa.eu/legalcontent/EN/TXT/HTML/?uri=CELEX:32012L0027\&from=EN

12. https://ec.europa.eu/eurostat/cache/metadata/EN/nrg_ind_eff_esms.htm 


\section{IRENA. (2020). GLOBAL LANDSCAPE OF RENEWABLE ENERGY}

FINANCE. Available https://www.irena.org/-

/media/Files/IRENA/Agency/Publication/2020/Nov/IRENA_CPI_Global_finance_20 20.pdf

14. Rosenberg, A., Schopp, A., Neuhoff, K., \& Vasa, A. (2011). Impact of Reductions and Exemptions in Energy Taxes and Levies on German Industry. Available https://www.climatepolicyinitiative.org/wpcontent/uploads/2011/12/Reductions-and-Exemptions-on-Energy-Taxes.pdf 15. Stern, D.I., Cleveland, C.J., 2004, Energy and Economic Growth, Rensselaer Working Papers in Economics No. 0410, Rensselaer Polytechnic Institute, USA.

16. UKRAINIAN ASSOCIATION OF RENEWABLE ENERGY. (2021, February 21). Available https://uare.com.ua/en/

17. UNEP. (2012). Feed-in Tariffs as a Policy Instrument for Promoting Renewable Energies and Green Economies in Developing Countries. Available https://unfccc.int/files/documentation/submissions_from_parties/adp/application/pdf /unep_us ws2.pdf

18. United Nations. (2015). Transforming our World: The 2030 Agenda for Sustainable Development. Available https://sustainabledevelopment.un.org/post2015/transformingourworld/publication 19. Stern, D.I., Cleveland, C.J., 2004, Energy and Economic Growth, Rensselaer Working Papers in 20. Economics No. 0410, Rensselaer Polytechnic Institute, USA; https://www.researchgate.net/publication/24125107_Energy_and_Economic_Grow th

21. Bian, Y., Hu, M., Wang, Y., \& Xu, H. (2016). Energy efficiency analysis of the economic system in China during 1986-2012: A parallel slacks-based measure approach. Renewable and Sustainable Energy Reviews 55, 990-998. Available https://www.sciencedirect.com/science/article/abs/pii/S1364032115012605?via\%3 Dihub

22. Filippini, Massimo, Hunt, Lester C. (2015). Measurement of Energy Efficiency Based on Economic Foundations. Energy Economics, 1-34. Available https://www.sciencedirect.com/science/article/pii/S0140988315002467?via\%3Dihu b

23. Malinauskaite, J., Jouhara, H., Ahmad, L., Milani, M., Montorsi, L., \& Venturelli, M. (2019). Energy efficiency in industry: EU and national policies in Italy and the UK. Energy, 255-269. Available https://www.sciencedirect.com/science/article/pii/S036054421930146X

24. R. Cowart. (2014). Unlocking the Promise of the Energy Union: Efficiency First Is Key. The Regulatory Assistance Project, Montpelier, VT, Available https://www.raponline.org/document/download/id/7401/

25. Rosenow, J., Kern, F., \& Rogge, K. (2017). The need for comprehensive and well targeted instrument mixes to stimulate energy transitions: The case of energy efficiency policy. Energy Research \& Social Science. Available https://www.sciencedirect.com/science/article/pii/S2214629617302797 